\title{
Unhappy consciousness, one-dimensionality, and the possibility of social transformation
}

Arnold Farr*

Introduction

In his preface to Raya Dunayevskaya’s Marxism e freedom, Marcuse begins by saying:

The reexamination of Marxian theory is one of the most urgent tasks for comprehending the contemporary situation. Perhaps no other theory has so accurately anticipated the basic tendencies of late industrial society - and apparently drawn such incorrect conclusions and analysis.

\section{He continues:}

Marxian theory may be said to imply predictions. But the essential character of this theory denies such designation. Marxian theory is an interpretation of history and defines, on the basis of this interpretation, the political action which, using the given historical possibilities, can establish a society without exploitation, misery and injustice. Thus, in its conceptual structure as well as in its political practice, Marxian theory must "respond" to the historical reality in process: modification of the theoretical concepts and of the political practice to be guided by them is part of the theory itself (Marcuse, 2000, p. Xx). 
Marcuse's assessment of Marxian theory here could very well be applied to his own. Marcuse's One-dimensional man is a book that had an enormous impact during the decade of its publication and beyond. The tone of the book is one of political urgency and prophetic challenge tainted by what appears to be a spirit of pessimism. Indeed, Marcuse has often been accused of having mood swings as one work appears to be hopeful and optimistic while another appears to be rather pessimistic. Such views of Marcuse's work are based on a complete misunderstanding of the dialectical nature of his form of critical theory. The concept of one-dimensionality was used by Marcuse in reference to the avoidance of dialectical thinking in our society. Marcuse's use of dialectic will be discussed in the third section of this paper. My goal in this paper is to examine the development and function of Marcuse's concept of one-dimensionality. I argue that the concept has its origin in Hegel's notion of immediacy and can be traced form Hegel to Marx, to Lukács, to Marcuse. I will then briefly address Marcuse's later attempt to point out the possibility of moving beyond the one-dimensional society.

Theory, praxis, the democratic impulse of marcusean critical theory, and its contemporary relevance

Iris Marion Young begins the first of her book Inclusion and democracy with this statement:

Democracy is hard to love. Perhaps some people enjoy making speeches, or confronting those with whom they disagree, or standing up to privileged and powerful people with claims and demands. Activities like these, however, make many people anxious. Perhaps some people like to go to meetings after a hard day's work and try to focus discussion on the issue, to haggle over the language of a resolution, or gather signatures for a petition, or call long lists of strangers on the telephone. But most people would rather watch television, read poetry, or make love (Young, 2000, p. 16).

This passage by Young suggests that while democracy is an attractive idea it is not easily established. Establishing a democratic society takes more work than most of us are willing to contribute. This problem requires an analysis that is related to the one that I am going to provide in this paper but is not quite my focus here. I began with this quote by Young because it shows that even today democracy is not yet. I will not try to develop a theory of democracy here. This I've done elsewhere. My goal here is to examine Marcuse's critique of the form of social pathology that prohibits democratic social development. 
Consider a couple of passages from Marcuse. In One-dimensional man he writes: "A comfortable, smooth, reasonable, democratic unfreedom prevails in advanced industrial civilization, a token of technical progress" (Marcuse, 1964, p. 1). He continues:

Free election of masters does not abolish the masters or the slaves. Free choice among a wide variety of goods and services does not signify freedom if these goods and services sustain social controls over a life of toil and fear - that is, if they sustain alienation. And the spontaneous reproduction of superimposed needs by the individual does not establish autonomy; it only testifies to the efficacy of the controls (Idem, pp. 7-8).

In a 1968 panel discussion with Norman Mailer, Nat Hentoff and Arthur Schlesinger at the Friends Meeting House on Gramercy Park in New York entitled "Democracy has/hasn't a future... a present", Marcuse states: "So I would say democracy certainly has a future. But in my view it certainly does not have a present" (Marcuse, 2005, p. 88).

If we return to the quote by Young it appears that democracy is hard to love because of the enormous effort that it requires. The absence of a real democratic process of decision making seems to be the result of laziness. I believe that at some level this is true. But I also believe that something else is going on that demands a return to Frankfurt School critical theory, especially that of Herbert Marcuse. It is also important to remember that first generation critical theory did not claim to be developing a theory of democracy, but their project was driven by an undeniable democratic impulse. The project of liberation as developed by Marcuse entailed a demand for a non-repressive society, adequate resources for the proper self-development and self-determination of all individuals, participation in the decision-making processes by which one's life is affected etc. It is not my purpose here to develop a theory of democracy. In fact, this paper is not about democracy in any direct way, but it is an analysis of the failure of Western societies to develop the necessary conditions for a democratic and liberated society. Put another way, there is a significant gap between the ideal of democracy or democracy in theory and concrete day to day democratic praxis.

Marcusean theory and liberation praxis represents an attempt to remedy the above-mentioned problem via the unification of theory and practice. It is not an attempt to unify two things that are separate then combined. Marcusean theory itself is at once transformative theory and praxis. In the spirit of Karl Marx, theory (philosophy) must transcend itself in praxis. Theory seeks actualization in praxis while praxis seeks expression and clarification (and in some cases guidance) in theory. The 
unity of theory and praxis in Marcuse must be disclosed by first examining the crisis of theory which is at the same time the crisis of praxis. We might say that marcusean theory is an examination of the social forces or social pathologies that prohibit the unity of theory and praxis or blocks the material realization of democratic ideals. This social pathology is the target of Marcuse's social analysis is one-dimensional thinking.

\section{A brief history of the concept of one-dimensionality}

The marcusean concept of one-dimensionality has its origin in the hegelian/marxian attempt to diagnose a certain social pathology that permeates western society and is also a direct result of the capitalist system of production. The hegelian concept of immediacy and the marxian concept of alienation are the precursors to Marcuse's notion of one-dimensionality. We will examine Marcuse's use of dialectics a bit later, for now we must understand that the very movement of the dialectics as motivated by the need to overcome immediacy. From the Phenomenology of spirit to the Philosophy of right, Hegel's project was to open the door for a liberated human community, a community that was prohibited by the human refusal to transcend immediacy. In the hegelian context, immediacy itself is a form of one-dimensional thinking that reduces all reality and its complexity to the immediate presentation of things. In almost every text the method is to begin with the most popular and commonplace shapes or forms of thought and demonstrate the inadequacy of this shape of thought and the contradictions entailed by it. To simply take things as they are given is to ignore the principle of change within the given. This principle of change is the essence of the thing that comes to fruition only under the proper conditions of development. With respect to humanity the proper conditions of development include proper thinking about who we are and what is our potential. Hence, human self-actualization requires a new form of thinking that moves beyond immediacy and recognizes that all human social reality is mediated.

The focus on mediation reveals to us the social nature of our existence or, as Terry Pinkard (1994) suggests, it discloses the sociality of reason. This becomes evident in Hegel's critique of abstract right and morality in his Philosophy of right. Since this is not a paper about Hegel, I will not get into the details of Hegel's arguments here. In short, Hegel demonstrates how the traditional focus on rights and morality isolates the individual from his or her social context of development. As a result, we end up with isolated individuals who are not able to free themselves from a war of all against all situation, instead of a human community based on freedom, equality, and mutual recognition. Even social contract theory is incapable of creating human community insofar as human beings enter the contract as isolated, self-contained, 
atomistic individuals who are concerned only with protecting their private interests. The social contract protects the immediacy of individual consciousness instead of transcending it. Therefore, even some of our most interesting and seemingly liberating social/political philosophies are still one-dimensional.

One way of understanding the connection between Hegel's critique of immediacy and Marcuse's concept of one-dimensionality is to read the preface to the 1960 edition of Marcuse's second book on Hegel entitled Reason and revolution: Hegel and the rise of social theory. This preface, entitled "A note on dialectics", begins with the claim that this book is not an attempt to revive Hegel but rather a way of thinking. Marcuse calls this way of thinking negative thinking. Negative thinking is dialectical or two-dimensional thinking. The negative here is the Hegelian negation of negation. I will not go into detail here regarding Hegel's negation of negation. A more marcusean understanding of this activity is simply to think about the way in which oppressive and repressive social forces put under erasure certain possibilities for human development. This putting under erasure is a negation of human potential that can be overcome only by another negation, the negation of negation. This second negation liberates the previously oppressed individual or group and sets free the democratic processes of self-development and self-determination. However, the second negation becomes effective only when we think two-dimensionally, that is when we see in the present order of things their own principle of negation. Every social formation contains its possible other. The social facts at every moment contain the possibility of their own transformation. A good example of this is Marcuse's critique in Eros and civilization of the so-called problem of scarcity. Due to advanced technological development, scarcity is no longer a problem. We have the resources to end world hunger. However, the idea of scarcity is required by capitalism and its obsession with production just for the sake of production. The problem is no longer scarcity but the hierarchical distribution of scarcity. So, already in Marcuse's work on Hegel we see the seeds of his theory of one-dimensionality.

For Marx, alienation under capitalism is the first negation that must be negated by revolution. Also, is a result of a distorted and pathological labor process. Following Hegel, Marx believed that through labor human beings externalized their wills and achieved self-actualization in the world. Through labor we create our world and ourselves. Unlike Hegel, however, Marx was more aware of the negative, alienating, dehumanizing turn that labor took under capitalism.

The capitalist system is structured in a way that dehumanizes rather than humanizes. The worker not only produces commodities which benefit someone else, he or she becomes a commodity, a thing. Marx (2000a, pp. 89-90) discusses four forms of alienation: 
- Man is alienated from nature (alienated from the products of his labor).

- Man is alienated from himself as worker (his labor does not offer him satisfaction, but it offers satisfaction to someone else).

- Man is alienated from his product and the process of production (hence, man is estranged from his humanity and nature).

- Man is alienated from his fellow human beings and his own nature (human relationships are I-it relationships and not I-thou relationships).

I will not discuss Marx's theory of alienation in any detail here. Suffice it to say that alienation refers to the gap between our daily practice and way of being in the world and our best selves under non-alienating, non-dehumanizing, non-repressive social structures. This theme (contrary to Althusser's questionable distinction between the early humanist Marx and the later non-humanist Marx) stays with Marx with a few modifications.

In Capital the theme of alienation occurs again as the problem of commodity fetish. Through commodity fetish economic forms of capitalism conceal underlying social relations. Marx writes:

A commodity is therefore a mysterious thing, simply because in it the social character of men's labor appears to them as an objective character stamped upon the product of labor; because the relation of the producers to the sum total of their own labor is presented to them as a social relation, existing not between themselves, but between the producers and their labor. This is the reason why the products of labor become commodities, social things whose qualities are at the same time perceptible and imperceptible by the senses (Marx, 2000b, p. 473).

We see that commodities function in a similar way to ideology in Marx's analysis of false consciousness. This idea occurs again in the Marxist literature in the 1923 work of Georg Lukács' History and class consciousness as the concept of reification. Lukács describes reification as follows:

That is to say, the contradiction that appears here between subjectivity and objectivity in modern rationalist formal systems, the entanglements and equivocations hidden in their concepts of subject and object, the conflict between their nature as system created by "us" and their fatalistic necessity distant from and alien to man is nothing but the logical and systematic formulation of the modern state of society. For, on the one hand, men are constantly smashing, replacing and leaving behind the "natural" irrational and actually existing bonds, while, on the other hand, they erect around themselves in the reality they have created and made a kind of second nature which evolves with exactly the same inexorable 
necessity as was the case earlier on with irrational forces of nature (more exactly: the social relations which appear in this form). "To them, their own social action", says Marx, "takes the form of the action of objects, which rule the producers instead of being ruled by them" (Lukács, 1971, p. 128).

In the chapter entitled "Reification and the paradigm of rationality" in his book Lukács, Marx and the sources of critical theory, Andrew Feenberg writes:

Fetishism characterizes a society in which the economic relations between the individuals are governed by the forces they unleashed through their unplanned interactions on the market. In such a society, the "law" of the market takes on an independence and power, a "material character," the individuals themselves increasingly lose (Feenberg, 1981, p. 61).

We find a precursor to this type of critique in Hegel's concept of appearance or immediacy. Reified thought is non-dialectical, and it lacks mediation or is unable to understand the role of mediation. We take the world as it is to be fact. But, all facts are mediated facts. This is why Marx could say that men create their own history but not under the conditions of their choosing.

Reified thought seems to have a function that is much like the first form of alienation discussed by Marx. The product is produced by the worker but not owned by the worker. Here we have a situation whereby the worker does not find him or herself by externalizing their will in the process of production. They have become objects or (in the words of Horkheimer and Adorno) mere functions that carry out the will of someone else for the satisfaction of someone else. Labor itself becomes a commodity, thereby making the worker an object.

I want to belabor this point. The lukácsian concept of reification not only applies to the worker but also to the bourgeoisie. In this case the social world is a product that has its origin in human relations. Reified thought can be characterized as a form of social amnesia whereby we forget that the social world in which we live, with all of its injustice, inequality, violence, racism, sexism, homophobia, poverty etc., is our own creation. Social change, therefore, is in our hands. However, the function of reification is to put human agency under erasure. The social world as it is is taken to be an immutable fact. However, this immutable fact actually requires a lot of effort for its maintenance. Hence, the stabilization of reified thought requires work, administration. Hence, Horkheimer and Adorno's "administered society" is a society whereby reified thought is maintained via a system of regulation whereby ideas, human agency, praxis, values, moral concepts etc., are regulated and manipulated so that progressive social change is stifled. 
Marcuse's path to the theory of one-dimensionality

The movement which we call Western marxism and of which Marcuse was a part can be characterized as the quest for revolutionary consciousness. It emerges from a context where the marxist revolution was highly anticipated but never materialized. What did materialize instead were very brutal totalitarian systems. The task that befell Marxist and progressive thinkers was that of explaining why the revolution never took place or why those who would benefit most from the revolution are most likely to resist it. This is why Freudian psychoanalysis became a central component of critical theory. What was discovered is that the capitalist system embodied the social mechanisms whereby revolutionary consciousness is put under erasure or to use one of Marcuse's terms "whittled down". Here we are able to respond to Young's discussion about why democracy is hard to love. Laziness and fatigue at the end of the day are only partial explanations. Another view suggests that the self-formative processes in which the consciousness of the individual is formed in a capitalist society paralyzes critical consciousness. This is precisely the problem or pathology that is the target of Marcuse's form of critical theory.

Before we examine Marcuse's theory of one-dimensionality we must situate his work within the Western Marxist quest for revolutionary subjectivity. We are familiar with the Marxian view that eventually the contradictions of capitalism would become so great that it would produce its own gravediggers, the proletariat. Once the proletariat achieved class consciousness, that is, awareness of the way in which it is exploited by capitalism it would rise up and overthrow the system by which it is oppressed. Marcuse begins writing at a time when these hopes had waned, and he rarely refers to revolution or the proletariat. What seems to be lost is the event that was to come, revolution, and the subject or subject/object of the revolution, the revolutionary class, the proletariat, the revolutionary class endowed with revolutionary consciousness.

In his early days at the Frankfurt School there were two problems that preoccupied Marcuse and would shape his entire critical project. The problems were those of negation and social change. In addition to Marx, Hegel also exercised a profound influence on Marcuse. Hegel's influence on Marcuse was not just a linear one, taken up only through Marx. Indeed, Marcuse first two books were on Hegel. For Marcuse Hegel's importance lies in his radically new way of seeing and understanding social reality. I will come to the problem of negation (which serves as the foundation for Marcuse's concept of one-dimensionality) later. Let's begin with the problem of social change.

In the early 1940s Marcuse undertook a research project on social change with his friend Franz Neumann that he never abandoned. Indeed, One-dimensional man is a continuation of this project. Among Marcuse's unpublished writings are "A his- 
tory of the doctrine of social change" and "Theories of social change" both written in the early 1940's with Franz Neumann. In 1965, one year after the publication of One-dimensional man, Marcuse presented a talk at Stanford University entitled "The containment of social change in industrial society". Although I have argued elsewhere that Marcuse's project remained consistent from his 1933 book on Hegel to his 1878 book on Marxist aesthetics (Farr, 2009) I will for the moment use the unpublished writings just mentioned as bookends for Marcuse's project since my focus here is on one-dimensionality.

Marcuse and Neumann's interest in social change grows out of their growing awareness that there is something in the capitalist system that makes revolution less likely than earlier Marxists thought. However, the analysis of social change and social containment does not give birth to pessimism. It is in fact, a broadening of the Marxian analysis of capitalist society. We know that Marx claimed that in every epoch the ideas of the ruling class become the ruling ideas. What is not explained is how this happens. Marcuse and Neumann begin by an examination of the history of the doctrine of social change. They write:

The dialectical conception of change was first elaborated in Hegel's philosophy. It reversed the traditional logical setting of the problem by taking change as the very form of existence, and by taking existence as a totality of objective contradictions. Every particular form of existence contradicts its content, which can develop only through breaking this form and creating a new one in which the content appears in a liberated and more adequate form (Marcuse and Neumann, 1998, p. 130).

They continue:

Social change was no longer an event occurring in or to a more or less static system, but the very modus existentiae of the system, and the question was not how and why changes took place but how and why an at least provisional stability and order was accomplished (Idem, p. 131).

In "Theories of social change" Marcuse and Neumann claim that until the 18th century the theory of social change has always been a philosophical theory. They outline the history of theories of social change, a history that they planned to treat in greater detail in a future work. While this future work was never produced, there is enough in this essay to shed light on Marcuse's growing concern about social containment or one-dimensional thinking. Of importance to us here is the transition of theories of social change from static to dialectical. 
In the above passages Hegel is credited with being the first to elaborate a dialectical conception of social change. The static conception of social change viewed society as more or less stable. Change occurs within a previously stable society as a rupture or break. The dialectical conception views society as perpetual motion, constant change driven by the constitutive contradictions of that society. Here we are at an important and interesting place and will soon be able to unpack Marcuse's later theory of one-dimensionality.

Let's begin by examining the way in which the Hegelian dialectical theory of social change differs in its marxian form from its marcusean form. The marxian form shares with the hegelian form a certain naïveté that is not found in Marcuse's version in spite of claims to the contrary. We may say that Marx and Hegel never completely freed themselves from a certain enlightenment pathology. That is, both Hegel and Marx remained wedded to a form of messianism or religious eschatology, or a naïe emancipatory telos wherein history was naturally being moved toward a moment of reconciliation (Hegel's view) or a classless society (Marx's view). Of course, Marx and Hegel differ greatly on who the agents of change are and the method by which change would be brought about. Nevertheless, the establishment of something like the Kingdom of God on earth was inevitable.

The concept of the Kingdom of God here need not be taken in a religious sense. It is an extension of the kingdom of ends formulation of Kant's categorical imperative. It simply refers to a harmony of human wills so that no human being is willing to be oppressed by nor oppress another. This version of the dialectical conception of social change sounds a bit utopian. Indeed, many readers of Eros and civilization have accused Marcuse of a blind utopianism while some readers of One-dimensional man accuse him of a paralyzing pessimism. Both of these criticisms quickly fall away if one understands Marcuse's own view of dialectical thinking. Let's proceed by returning to the last sentence of the first quote that I read from "Theories of social change". "Every particular form of existence contradicts its content, which can develop only through breaking this form and creating a new one in which the content appears in a liberated and more adequate form". At first glance it seems an odd thing to say, "Every particular form of existence contradicts its content". This statement becomes less obscure if we think about it in terms of Aristotle's distinction between actuality (particular existence) and potentiality (content). That which is potential is potential as latent, or repressed, or unfulfilled, or embryotic actuality. Another way of thinking about it is in terms of promises made but not fulfilled. Such as the promise of equality, respect, equal opportunity, fairness, justice, peach, well-being, self-determination, adequate resources for self-development, democratic discourse, equal pay for equal work etc. 
Simply put, there is a gap between the potential of a society and its promises and its actual state of existence. In the spirit of the Hegelian/Marxian tradition Marcuse's project is a form of what Seyla Benhabib calls immanent critique. In Critique, norm, and utopia: a study of the foundations of critical theory, Benhabib makes an important distinction between criticism and critique (which she calls immanent critique):

Critique refuses to stand outside its object and instead juxtaposes the immanent, normative self-understanding of its object to the material actuality of this object. Criticism privileges an Archimedean standpoint, be it freedom or reason, and proceeds to show the unfreedom or unreasonableness of the world when measured against this ideal paradigm (Benhabib, 1986, p. 51).

As I said before, Marcuse's theory cannot legitimately be interpreted as a blind utopianism guided by a hope for a perfect or more reasonable world on the basis of some external context-transcending ideal. His critique is an immanent and disclosing critique. It may be argued by a less sympathetic reader of critical theory that the critical theorists and Marcuse especially do have some kind of reasonable or rational ideal in mind. This is true, but, it is an ideal that is promised by the very society that they are critiquing. Hence, our society does not contradict some context-transcending normative ideal, it contradicts its own content, its own promises.

Now we are at the point where we can begin to unpack Marcuse's concept of one dimensionality. If, for Marx and early Marxists, social contradictions are supposed to move society toward social change and a less alienated and more liberated form of existence, why has such movement or change not occurred? Marcuse's position is that these contradictions are smoothed over or made unrecognizable. Just as contradictions are a part of the system so are the mechanisms whereby these contradictions are concealed. Marcuse's critique of one-dimensional thinking is his attempt to explore the mechanisms whereby these contradictions are concealed for the purpose of pointing the way to a new, or not so new, type of thinking. In his new 1960 preface "A note on dialectics" to his 1941 book on Hegel Reason and revolution, Marcuse writes:

This book was written in the hope that it would make a small contribution to the revival, not of Hegel, but of a mental faculty which is in danger of being obliterated: the power of negative thinking (Marcuse, 2007, p. vII).

He continues: 
Today, this dialectical mode of thought is alien to the whole established universe of discourse and action. It seems to belong to the past and to be rebutted by the achievements of technological civilization. The established reality seems promising and productive enough to repel or absorb all alternatives (Idem, ibidem).

In this context let me remind you of an earlier quote from Marcuse and Neumann in their essay "Theories of social change": "Social change was no longer an event occurring in or to a more or less static system, but the very modus existentiae of the system, and the question was not how and why changes took place but how and why an at least provisional stability and order was accomplished" (Marcuse and Neumann, 1998, p. 131).

This is mentioned as one of the five consequences of the hegelian conception of social change, but it is the one that is of most importance for our purpose. Social change occurs in this case as the mode of existence of the system. Marcuse's term one-dimensionality is used as a synonym for the containment of social change. Notice, there is no claim here that social change does not occur. The claim is that social change is contained, restricted, limited by the system. The form of social change that occurs is shaped by the system itself. Therefore, the form of social change that occurs in designed to keep this system in place. Hence, the occurrence of social change still gives the appearance of stability and order since social change is the work of one and the same system making the necessary modifications and adjustments to preserve itself. Therefore, the change is designed to maintain oppressive and repressive social structures while creating the façade of liberation.

In the passage quoted from the 1960 preface of Reason and revolution, the term negative thinking is another term for what Marcuse in One-dimensional man calls two-dimensional thinking. Such thinking is simply the ability to recognize the contradictions present in our society and to imagine (on the basis of present unrealized potential) the possibility for an alternative existence. However, the ability to recognize social contradictions and to imagine an alternative existence is obliterated by the present reality principle.

Two-dimensional or negative thinking is the positive negation of the present social system. In a one-dimensional society the capacity for two-dimensional thinking is whittled down. Such critical consciousness goes under erasure when the system creates and then fulfills what Marcuse calls "alien needs". While the basic needs of liberty, equality, freedom from surplus toil, resources for self-development and selfdetermination go unmet the choice of a wide range of goods or commodities and television programs create the façade of autonomy. In a 1978 interview with Brian McGee, Marcuse, reflecting on Marx's claim that the working class had nothing to lose 
but their chains states that today this is no longer true, they have considerably more to lose. For example, if the worker revolts he is easily replaced by another and he might lose the freedom to come home after work and recline with a few beers and a football game on television or pornography on the internet. Marcuse makes the point as follows:

The people enter this stage as preconditioned receptacles of long standing; the decisive difference is in the flattening out of the contrast (or conflict) between the given and the possible, between the satisfied and the unsatisfied needs. Here, the so-called equalization of class distinctions reveals its ideological function. If the worker and his boss enjoy the same television program and visit the same resort places, if the typist is as attractively made up as the daughter of her employer, if the Negro owns a Cadillac, if they all read the same newspaper, then this assimilation indicates not the disappearance of classes, but the extent to which the needs and satisfactions that serve the preservation of the Establishment are shared by the underlying population (Marcuse, 1964, p. 8).

Today we feel united if we root for the same football team. We are in solidarity as we eagerly await the crowning of the next top model or American Idol. Poor working-class people are content with their poverty if the 32 million offered to the new basketball coach leads to the winning of a championship for the team with whom they identify. The worker and his boss discuss with intrigue the insights that they've gained from listening to a serious debate between men in suit and tie on SportsCenter about who will win the Super Bowl and why. The typist and the bosses' daughter share with each other their Brad Pitt fantasies. Poor inner-city youth and rich suburban youth engage each other in a serious discussion about who has the best flow Lil Jon or Lil Wayne. In the midst of all of this there is no critique of the gross inequalities that exist between the social groups to which these individuals belong. There is no critique of the abundance of resources and opportunities for one group and the scarcity of such for the other. There is no critique of the material conditions that divide these groups. There is no critique of who is most likely to be harassed by the police, die of AIDs, get shot in a drive-by, go to or not go to college. There is no critique of why one group will have ample resources to pass on to future generations and the other none.

One-dimensionality and the conquest of the unhappy consciousness: Marcuse's freudo-marxian reading of Hegel and contemporary society

It is well known that Marcuse was influenced by Hegel, Marx, and Freud. However, how these three thinkers are taken up by Marcuse at certain moments of his own 
theoretical development is not always clear. Chapter three of One-dimensionalman, entitled "The conquest of the unhappy consciousness: repressive desublimation" is an interesting translation of a hegelian problem into a freudo-marxian framework. The notion of the unhappy consciousness contains an awareness or even a demand for social change and the resistance to social change at the same time. Unpacking this idea and distinguishing between its hegelian and its freudo-marxian forms is important for understanding the problem of the unity of theory and practice as well as understanding the possibility/impossibility of social change.

The social situation of the domination of one group by another, whether it be class domination, race or gender-based domination, domination based on sexual orientation etc., is a form of the master/slave relationship described by Hegel in chapter four of his Phenomenology of spirit. To briefly review Hegel's story, Hegel believed that what distinguished human beings from other animals was our need to be more than desiring machines who merely consume the objects of their desire. The idea here is to find a relationship that cannot be reduced to the subject/object relationship. Human beings not only desire the objects that they consume to satisfy a physical need, they also desire to be desired. Hegel calls this the desire for recognition. I am human to the extent that my humanity is recognized by another like myself. All violence, injustice, domination, oppression, exploitation etc. is the result of one human being or group of human beings denying recognition to another human being or group. That is, some human beings seek to receive recognition but not give it in return. They insist in maintaining the subject/object relationship wherein one person is the subject and the other is the object. One thinks of Martin Buber's distinction between the I-thou and the I-it relationships. In Marx, it is the Bourgeoisie who tries to maintain itself as subject while reducing the workers to mere objects whose only function is to produce more capital through their labor.

In Hegel's story, when two human animals meet each seeks recognition from the other while not being willing to grant it to the other. This leads to the struggle for recognition which is a fight to the death unless one of the parties gives up to save one's life. The one who gives up becomes the slave of the person who did not give up. This is the formation of the master/slave relationship. However, this relationship is contradictory at several levels and must be overcome. There is not time here to deal with all of these contradictions. There is one that is relevant for what Marcuse is doing in chapter three of One-dimensional man.

As the slave works and toils with nature for the benefit of the master he becomes aware of the contradictory nature of his relationship with the master and with himself. The slave can choose to confront the master and demand his freedom and the recognition that goes with it or he can construct false narratives about how he 
is really free. Each narrative still presents the slave with intolerable contradictions. Hence, the slave goes through stages of what we may call false consciousness. It is the final form of false consciousness that is important to us here. The final stage of false consciousness discussed is unhappy consciousness.

In unhappy consciousness, the external and objective duality between master and slave is internalized. This produces a split in consciousness. The master and the slave become two sides of one and the same consciousness. Within consciousness a binary system is set up; the changeless and the changing, the essential and the unessential, the universal and the particular, the master and the slave, the infinite God and the finite person. The slave now sees his/herself as not dominated by or working in the service of her earthly master, but rather, as working in the service of her heavenly master.

The unhappy consciousness attempts to escape the master/slave relationship by achieving a unified self-consciousness and recognition from her relationship with the immutable. The unhappy consciousness is an awareness of the contradictory form of life lived by the slave, or any finite rational being. The labor of the slave, the process of toiling with and transforming nature so that nature conforms to the human will gives the slave a sense of freedom and power. However, this toiling with and transforming nature is for the purposes of someone else, the master. Therefore, the feeling of freedom and unfreedom arise at the same time. The slave experiences herself as a contradiction. There is a consciousness of freedom and slavery in the same being. The slave attempts to overcome this contradiction by subsuming all life under slavery. Hence, slavery becomes the universal unifier of all humanity.

This development within self-consciousness is still pathological insofar as it maintains a pathological and contradictory relationship. Further, it encourages the pathology of denial. The view that all is slavery conceals the social reality of slavery or the domination of one social group by another. The wrongness of human domination, oppression, alienation, and exploitation goes unchallenged. To seek freedom in the Beyond is to reject our responsibility to each other in this world. The world view of the unhappy consciousness is irrational to the extent that reason cannot be separated from the idea of a community of free rational agents who mutually recognize one another.

Unhappy consciousness is an inadequate shape of consciousness for at least two reasons. First, it must posit an existence that cannot be known. The Beyond does not lend itself to human observation. Secondly, and more importantly, it does not lead to the type of self-overcoming that creates human community by abolishing the master/slave relationship. Instead, it reproduces what H. S. Harris called the singular will. As unhappy consciousness the singular is split into two and oscillates 
between its two sides. It imagines the One Will that is done in Heaven while also being cognizant of the will that should be done on earth. That is, what should be done on earth is put off in the Beyond.

In Hegel's philosophy, self-consciousness continues to struggle and go through various inadequate shapes of consciousness until it eventually overcomes its contradictions in absolute knowledge. At this point, the master and slave relationship is abolished as the master and slave are reconciled as mutually recognized and mutually recognizing members of the human community. However, as we know, we are nowhere near such a happy ending. Hegel's phenomenology is supposed to be a descriptive account of the rational development of the human species. The various shapes of consciousness through human beings pass seem to be correct. However, he/ she moves too quickly to the moment of reconciliation. For Marcuse, the unhappy consciousness is a social reality. Nevertheless, left within the Hegelian framework, the analysis of the formation of unhappy consciousness does not help much with understanding our present situation and the possibility or impossibility for social change. Hence, Marcuse resurrects the notion of the unhappy consciousness within a freudo-marxian framework.

Marx goes beyond Hegel by developing a deeper analysis of one form of the master/slave relationship. In a marxian context the master/slave relationship is the bourgeoisie/proletariat relationship. With Marx we get a detailed critique of capitalism and how it produces and maintains the master/slave relationship. We also get a detailed examination of the contradictions produced by capitalism. Marx, however, remains trapped to some extent in the Hegelian web of optimism insofar as he believed that the proletariat would eventually develop revolutionary consciousness and fight to emancipate themselves. Freud aids critical theory in going beyond Marx by disclosing the social mechanisms at work in society that, in Marcuse's terms, whittles down critical consciousness. It is in this framework that we must examine unhappy consciousness.

Unhappy consciousness is unhappy because it is unable to be in harmony with itself due to the contradictions by which it is constituted. Due to its internalization of the master/slave duality it is a split consciousness and cannot even be reconciled to itself. It is unhappiness that makes one seek something other, a different reality principle, social change. The unhappy consciousness cannot rest until it is unified with itself, which requires being unified with others in freedom and community. However, Marcuse speaks of the conquest of the unhappy consciousness. That is, the unhappy consciousness has been conquered in such a way that it no longer strives for liberation and unity. It is forced to remain content within the master/ slave relationship. How does this happen? 
In a 1978 interview with Brian McGee, Marcuse expresses disagreement with Marx's claim that the working class has nothing to lose but its chains. Marcuse says that we know today that it is not the case that the working class has nothing to lose but its chains, it has considerably more. What he means is that the system is designed to give the working class just enough goodies to make them happy momentarily. False needs are imposed on the working class then satisfied. This theme is discussed throughout the book. However, in chapter three he focuses on the way in which the space for critical/unhappy consciousness is put under erasure. This chapter is in some ways a restatement of his 1937 essay "The affirmative character of culture". In both texts Marcuse's position is that artistic alienation is an expression of unhappy consciousness. Artistic alienation is oppositional, and it is a rejection of the present oppressive reality principle. However, this opposition has been flattened out, put under erasure by its acceptance in mainstream society. That which attempts to resists the established order is taken up by that order. In a one-dimensional society, the gap between art and the present reality principle is closed. The critical function of art and education as well is assimilated by the oppressive social order. As Marcuse says, "the Great Refusal is in turn refused". He goes on:

The neo-conservative critics of leftist critics of mass culture ridicule the protest against Bach as background music in the kitchen, against Plato and Hegel, Shelly and Baudelaire, Marx and Freud in the drugstore. Instead, they insist on recognition of the fact that the classics have left the mausoleum and come to life again, that people are just so much more educated. True, but coming to life as classics, they come to life as other than themselves; they are deprived of their antagonistic force, of the estrangement which was the very dimension of their truth. The intent and function of these works have thus fundamentally changed. If they once stood in contradiction to the status quo, this contradiction is now flattened out (Marcuse, 1964, p. 64).

The unhappy consciousness that was once reflected in the "classics" has been whittled down and assimilated. As "classics" these works are taken up as merely the past with no relevance for the present. Hence, everyone can read Freud or Marx and completely miss the critique of the present order of things. One can read for mere personal edification. In this situation the unhappy consciousness no longer stands in opposition to society as the demand for a new reality principle, it is made to feel at home in the present society. 
Prospects for liberation: beyond one-dimensional pathology

I want to now turn to a body of work by Marcuse after the publication of One-dimensional man wherein he attempts to outline a liberation praxis. I will draw from published material as well as some previously unpublished material which has just come into print thanks to the tireless efforts of Douglas Kellner in the U. s. and Peter-Erwin Jensen in Germany. In this material Marcuse continues to develop some of the themes already articulated in what some have called his most optimistic work, Eros and civilization (1955). In fact, in the mid to late 1960s and early 1970s Marcuse sees in the various political movements of the time a coming to fruition of some of the main themes of Eros and civilization. This is evident in the 1966 "Political preface to Eros and civilization" and the unpublished "Beyond one-dimensional man”, 1968.

I will cite at length a passage from each of these texts and then connect them to some key themes in Eros and civilization. Marcuse writes in the "Political preface":

Eros and civilization: the title expressed an optimistic, euphemistic, even positive thought, namely, that the achievements of advanced industrial society would enable man to reverse the direction of progress, to break the fatal union of productivity and destruction, liberty and repression - in other words, to learn the gay science (gaya sciencia) of how to use the social wealth for shaping man's world in accordance with his Life Instincts, in the concerted struggle against the purveyors of Death. This optimism was based on the assumption that the rationale for the continued acceptance of domination no longer prevailed, that scarcity and the need for toil were only "artificially" perpetuated - in the interest of preserving the system of domination (Marcuse, [1966] 2001, p. 97).

In "Beyond one-dimensional man" he writes:

And, now apparently the collapse of this entire universe of discourse, and the rebellion against it on all fronts, in theory and in practice, in the student revolt of our days, in the Black Power Movement, in Vietnam, in Chicago. These are not some of the normal problems that beset a dynamic society, they are a questioning, an indictment and refusal of the whole. The very essence of this society has become questionable, its comforts as well as its evils. This rebellion experiences the absurdity of this society, the absurdity of reason, the destructiveness of its productivity, and the unbearable contrast between technical and human progress. So we can almost paraphrase Hegel's famous pair of propositions in saying: the real is absurd and the absurd is rational. (Marcuse, [1968] 2001, p. 112). 
There are two distinct yet related things going on in these two passages that are constitutive of a marcusean liberation praxis that he is in the process of developing in the last decade and a half of his life, and which also flows from the emancipator insights of Eros and civilization. First, one of the main themes of Eros and civilization is that although individuals are repressed in a one-dimensional society, this repression is never total. Marcuse attempts to use Freud against Freud by suggesting that the instinctual structure of the human being is malleable, capable of being shaped by social and historical forces. Indeed, even Freud in his 1915 essay on repression indicates that repression of the human drives is not a one-time affair. Repression is never final. The repressed drives continue to assert themselves. For this reason, the task of repression is never complete but must assert its power over and over. One is reminded here of Derrida's notion of iterability or repetition.

The purpose of Eros and civilization is to explore the possibility of liberation and resistance in the instinctual structure of the human being. In the 1960s Marcuse believed that the thesis of Eros and civilization was supported by the various forms of protest that were emerging. The protests of the 1960s were the result of the incompatibility of the desire or drives of individuals and the repressive social order. This connects the first passage to the second. I am reminded of Sartre's claim toward the end of Being and nothingness that nothingness lies at the heart of being like a worm. This worm is consciousness. In marcusean terms the unhappy consciousness lies at the heart of the one-dimensionally constituted happy consciousness. That is, the purpose of one-dimensional thinking in a one-dimensional society is to put all parts of the self, critical consciousness, first order desire, instincts etc., under erasure for the purpose of domination. One of the techniques of one-dimensional society, as we have discussed, is to create and satisfy false needs so that those who are dominated and oppressed will develop a happy consciousness in place of the unhappy consciousness produced by society. However, the unhappy consciousness lies like a worm at the center of one's instinctual structure waiting to uncoil. This is how Marcuse understood the protest movements of the 1960s. The rebellion was an instinctual rebellion as opposed to a rebellion based on the development of class consciousness.

Marcuse believed that the activists of the 1960s were motivated by the development of an internal intolerance of repression and the degree of exploitation, violence, and waste that they saw before them. We may argue that the protesters of the 1960 s, in addition to reacting to their own repression, also were able to see things from the perspective of Benjamin's angel of history. In fact, Marcuse always rejected the popular idea that his writings were somehow responsible for the revolts of the 1960s. In the process of rejecting this idea in an interview on the French Riviera in late summer 1968 Marcuse says: 
One of the essential characteristics of the student movement is that the students apply to reality what has been taught them in the abstract through the work of the masters who have developed the great values of Western civilization. For example, the primacy of natural law over established law, the inalienable right to resist tyranny and all illegitimate authority... They simply cannot comprehend why these great principles should remain on the level of ideas instead of being put into practice. And that is exactly what they are doing (Marcuse, 2005, p. 101).

I want to develop the main point of this passage a bit later as I work toward my conclusion. Suffice it to say here that we find in this passage a Marxian synthesis of idealism and materialism. Keep in mind that Marx's polemic against Hegel was due to Hegel's hyper idealism or the over emphasis on the spiritual at the expense of the material. His polemic against Feuerbach moved in the opposite direction. Feuerbach stressed the material at the expense of the spiritual (subjective).

Here we see the connection between the two passages cited earlier. Marcuse seems to indicate that the political protests of the 1960s have two possible sources for the development of critical consciousness. Both sources are material. First in Eros and civilization the material basis for the development of revolutionary consciousness is the potential resistance of the instincts. Second, critical consciousness emerges as a response to the recognized contradiction between the so-called democratic ideals that exist in theory only in a one-dimensional society and the refusal to allow these ideals to come to fruition in the material world although the material means for the actualization of these ideals are present.

So, at this point we've examined Marcuse's concept of one-dimensionality and its pathological effects. We've also just touched on Marcuse's hope for liberation and social change. Now, in the words of Lenin we may ask "what is to be done". There is no clear answer from Marcuse. Well, why read or re-read Marcuse? What is the point of this recent Marcuse revival? It is my position that Marcuse has left us with an entire arsenal of theoretical tools that must find their way back into contemporary political discourse. Our task is not to look to Marcuse or anyone else for answers. Instead, we must look for the clues left by Marcuse and others that must be taken up anew and further developed by us to meet our present challenges. Marcuse left use a wide range of concepts that are key starting points for further developing a liberation praxis. I will briefly list a few of them. Consider all of the chapter titles in An essay on liberation: "A biological foundation for socialism", "The new sensibility", "Subverting forces - in transition", "Solidarity", and others, "the great refusal", "catalyst groups", "the rationality of gratification", "libidinal relations", "non-repressive de-sublimation", "libidinal morality" etc. 
There is no time to examine the emancipatory potential of all of these ideas here. This is the future project that awaits all of us. Let me conclude by saying a word about my own recent attempt to reconstruct and further develop marcusean theory in a way that builds on the theoretical tools provided by Marcuse. First, we have seen that Marcuse believed that the political protest in the 1960s had two material foundations. The body of the individual protesters began to reject the repression that was experienced. There is a contradiction between the actual needs of the body and the society that represses the body. There is also a contradiction between the values and ideals of society and the material conditions under which people actually live. The abstractions that block liberation have their origin in Western philosophy with its primacy of Logos over Eros. This is the point of chapter five "A philosophical interlude" in Eros and civilization. I have attempted to follow Marcuse's lead here with my notion of the democratic body.

Another key concept for Marcuse is solidarity. Catalyst groups, in their struggle for the liberation of their own group tend to become one-dimensional and reductionistic. While they focus on their liberation for their own group the struggle of others undergo erasure. Indeed, dominant social groups are successful in maintaining their domination over groups to the extent that they are successful at keeping oppressed groups in isolation from each other. In my view solidarity requires what I have called democratic attunement.

Real democracy requires a decisive move beyond the abstract concepts and principles formulated by the "disembodied" logos of our tradition. Marcuse calls for the development of a new sensibility. This new sensibility would result from what I call democratic attunement. Democratic attunement is a form of sensual, embodied, Eros driven empathy that attunes us to the real, concrete material situation of the Other. The needs and desires of the Other are felt, recognized and understood. Democratic attunement is the basis for any authentic democratic discourse (Farr, 2009, p. 178).

In marcusean theory liberation and social change requires a transformation at several levels, from society as a whole to the instinctual structure of the individual. Where do we begin? One place for sure is education. The educational system in a one-dimensional society is one of the main contributors to the perpetuation of onedimensional thinking. It is also the place where our greatest hope for overcoming one-dimensional thinking resides. Recently, a number of marcusean scholars have begun a reconstruction of a marcusean theory of education. We also have for the first time several lectures delivered by Marcuse on education. In the introduction to Marcuse's challenge to education, Douglas Kellner et al. argues that in Marcuse's philosophy there is an important distinction between one-dimensional schooling and Bildung (cultivation). While traditional, one-dimensional education reproduces 
the status quo by merely preparing certain individuals to be successful or at least adjusted to the present reality principle. Indeed, such education is merely conformity to a capitalist performance principle.

Bildung concerns autonomous learning/self-formation, which incorporates the whole individual for the purpose of fully developing the self and society. This central ideal remains antithetical to any sense of formalism in education and instead embrace education of the body and mind against passive skill acquisition (Kellner et al., 2009, p. 7).

The task before us as educators is to be vigilant in our resistance to one-dimensional thinking. Our theorizing must not merely come from above, the domain of abstract principle and concepts, but from below, on the ground where real life and blood human beings, the victims of history, suffer and have their being. Human beings can no longer be simply defined as rational beings in the midst of so much irrationality. And, rationality itself must no longer be merely instrumental, but communicative, erotic, embodied. Marcuse developed some of the key ingredients for a liberated, democratic future. His project is not finished. In the summer of 1979 Marcuse passed the torch on to us. 


\section{References}

Benhabib, Seyla. (1986), Critique, norm, and utopia: a study of the foundations of critical theory. New York, Columbia University Press.

FARR, Arnold L. (2009), Critical theory and democratic vision: Herbert Marcuse and recent liberation philosophies. Lanham, Lexington.

Feenberg, Andrew. (1981), Lukács, Marx and the sources of critical theory. New Jersey, Rowman and Littlefield.

Kellner, Douglas et al. (2009), “Introduction”. In: Kellner, Douglas et al. (eds.). Marcuse’s challenge to education. Lanham, Rowman and Littlefield, pp. 1-33.

LukÁcs, George. (1971), History and class consciousness. Cambridge, The MIt Press.

Marcuse, Herbert. (1964), One-dimensional man. Boston, Beacon.

Marcuse, Herbert. ([1966] 2001), "Political preface to Eros and civilization, 1966". In: MARCuse, Herbert. Towards a critical theory of society. New York, Routledge, pp. 95-106.

Marcuse, Herbert. ([1968] 2001), “Beyond one-dimensional man”. In: Marcuse, Herbert. Towards a critical theory of society. New York, Routledge, pp. 107-120.

Marcuse, Herbert. (2000), "Preface”. In: Dunayevskaya, Raya. Marxism \& freedom: from 1776 until today. Amherst, Humanity, pp. xx-xxv.

Marcuse, Herbert. (2005), The new left, and the 1960s. New York, Routledge.

Marcuse, Herbert. (2007), “A note on dialectics”. In: Marcuse, Herbert. The essential Marcuse: selected writings of philosopher and social critic Herbert Marcuse. Boston, Beacon, pp. 63-71.

Marcuse, Herbert \& Neumann, Franz. (1998), “Theories of social change”. In: Marcuse, Herbert. Technology, war and fascism. New York, Routledge, pp. 105-138.

Marx, Karl. (2000a), "Economic and philosophical manuscripts”. In: Marx, Karl. Selected writings. Oxford, Oxford University Press, pp. 83-121.

Marx, Karl. (2000b), “Capital”. In: MarX, Karl. Selected writings. Oxford/New York, Oxford University Press, pp. $452-546$.

Pinkard, Terry. (1994), Hegel's phenomenology: the sociality of reason. Cambridge, Cambridge University Press.

Young, Iris Marion Young. (2000), Inclusion and democracy. Oxford, Oxford University Press. 


\section{Abstract}

Unhappy consciousness, one-dimensionality, and the possibility of social transformation.

The present article departs from concepts and ideas thoroughly developed by Herbert Marcuse. As such, it deals with his approach concerning the possibility of social transformation, looking to problematize the obstacles and hardships associated to the ongoing forms of social domination. To take this through, central works such as Eros and civilization and One-dimensional man are taken up, along with a number of lesser known texts and posthumously published reflections. Asserting the influence of Hegel, Marx and Freud, it is considered possible to criticize some of the existing contradictions that mark capitalist relations, interpreting them dialectically and immanently to unveil the potentials for social change through democratic attunement.

Keywords: Critical theory; Herbert Marcuse; Social transformation; One-dimensionality; Emancipation.

\section{Resumo}

Consciência infeliz, unidimensionalidade e a possibilidade de transformação social.

O presente artigo parte dos conceitos e ideias extensivamente desenvolvidos por Herbert Marcuse. Assim sendo, lidamos com sua abordagem sobre a possibilidade de transformação social, buscando problematizar os obstáculos e dificuldades associdados às formas correntes de dominação social. Para isso, trabalhos centrais como Eros e civilização e O homem unidimensional são analisados juntamente a textos menos conhecidos e reflexões publicadas postumamente. Afirmando a influência de Hegel, Marx e Freud, consideramos possível criticar algumas das contradições existentes que marcam as relações capitalistas, interpretando-as dialeticamente e imanentemente para desvelar os potenciais para mudança social por meio de sintonização democrática.

Palavras-chave: Teoria crítica; Herbert Marcuse; Transformação social; Unidimensionalidade; Emancipação.

Texto recebido em 28/5/2018 e aprovado em 18/6/2018.

DOI: 10.11606/0103-2070.ts.2018.146519.

ARNOLD FARR is professor of philosophy at the College of Arts \& Sciences at the University of Kentucky. E-mail: alfarr00@uky.edu. 